\title{
Aplikasi Teknologi Program Pengembangan Produk Unggulan Daerah (PPPUD); Produksi Ikan Hias Karang Lestari di Pulau Barrang Lompo, Makassar, Sulawesi Selatan
}

\author{
Akmal Abdullah', Mauli Kasmi 2, Karma3, Ilyas 4 \\ 1,2,3,4 Program Studi Agribisnis Perikanan, Politeknik Pertanian Negeri Pangkep \\ e-mail : akmalabdullah23@gmail.com ${ }^{1}$, karmaumar8@gmail.com ${ }^{3}$, $\underline{\text { ilyas 58@ymail.com }}$
}

\begin{abstract}
The potential of fishery resources in Indonesia is very abundant especially in South Sulawesi but has not been utilized to the fullest. This is because there is a lack of mastery of technological innovation handling coral ornamental fish, especially the production of marine ornamental fish. The objective of the Regional product development Program is to develop the business activities of a group of fishermen who are more self-reliant economically profitable and social, creating tranquility, comfort in community life and improving skills in a softskill and Hardskill, the number and quality of products increased to market, the product markets can be broadly open to export products, environmental health improvement, The method used is the socialization of PPPUD program. Training on how to capture and handle ornamental fish using Cleopatra nets and clove oil, operationalization and monitoring and evaluation program to ensure the sustainability and development of this PPPUD. The solutions offered in this activity is a more efficient decorative fish business management system and the results of ornamental fish products that are the standard export that will be applied to the East Marine SMES, as well as the implementation of the SME management system.
\end{abstract}

Keywords: Production, Marine Ornamental Fish, Cleopatra Nets, SMEs

\begin{abstract}
Abstrak
Potensi sumber daya perikanan di Indonesia sangat melimpah terutama di Sulawesi Selatan tetapi belum dimanfaatkan secara maksimal. Ini karena kurangnya penguasaan inovasi teknologi penanganan ikan hias karang, terutama produksi ikan hias laut. Tujuan Program Pengembangan Produk Daerah adalah untuk mengembangkan kegiatan bisnis dari sekelompok nelayan yang lebih mandiri secara ekonomi dan sosial, menciptakan ketenangan, kenyamanan dalam kehidupan masyarakat dan meningkatkan keterampilan dalam softskill dan Hardskill, yang jumlah dan kualitas produk meningkat ke pasar, pasar produk dapat secara luas terbuka untuk produk ekspor, peningkatan kesehatan lingkungan, Metode yang digunakan adalah sosialisasi program PPPUD. Pelatihan tentang cara menangkap dan menangani ikan hias menggunakan jaring Cleopatra dan minyak cengkeh, operasionalisasi dan program pemantauan dan evaluasi untuk memastikan keberlanjutan dan pengembangan PPPUD ini. Solusi yang ditawarkan dalam kegiatan ini adalah sistem manajemen bisnis ikan hias yang lebih efisien dan hasil dari produk ikan hias yang merupakan standar ekspor yang akan diterapkan ke UKM Laut Timur, serta penerapan sistem manajemen UKM.
\end{abstract}

Kata kunci: Produksi, Ikan Hias Laut, Jaring Cleopatra, UKM

\section{PENDAHULUAN}

Indonesia dikenal sebagai salah satu pusat keanekaragaman terumbu karang dan biota laut terbesar di planet ini dan sebagian besar terdapat di Kawasan Segitiga Karang Dunia. Tingginya keanekaragaman hayati ini berkontribusi secara signifikan tidak hanya dalam mempertahankan fungsi ekosistem laut, tetapi juga untuk sektor pariwisata, perikanan tangkap serta sumber bahan obat-obatan. Upaya perlindungan terhadap keanekaragaman hayati laut jelas sangat dibutuhkan, dan untuk mencapainya dibutuhkan strategi pengelolaan yang inovatif. Indonesia memiliki potensi sumberdaya ikan hias laut yang sangat besar jumlahnya serta memiliki nilai ekonomis tinggi. Beragam jenis ikan hias tersebut tersebar di berbagai perairan terutama menghuni habitat sekitar terumbu karang. 
Sebagian besar ikan hias hasil tangkapan dari perairan Indonesia itu, selain memenuhi permintaan konsumen lokal juga diekspor ke luar negeri dan menjadi sumber devisa negara yang potensial (Kasmi et al., 2014).

Pulau Barang Lompo merupakan salah satu bagian daerah spermonde yang memiliki perairan memiliki potensi terumbu karang yang cukup luas dengan variasi jenis ikan karang yang tergolong cukup banyak yang dapat dimanfaatkan sebagai ikan konsumsi dan ikan hias. Keragaman hayati yang besar, ekosistem beragam dan wilayah yang demikian luas dengan jumlah pulau-pulau yang banyak menimbulkan kesulitan dalam pengelolaannya yang optimal, termasuk dalam pemanfaatan biota laut hias. Hal ini dapat ditunjukkan oleh sedikitnya minat pengusaha biota laut hias. Sebagian besar cenderung memiliki usaha aquarium hias air tawar yang memiliki resiko usaha rendah dibanding usaha aquarium hias laut dengan resiko tinggi. Minat masyarakat dunia dalam aquarium hias laut semakin meningkat sementara minat pengusaha dibidang yang sama masih kurang dan pangsa pasar semakin terbuka, maka pengembangan usaha biota aquarium hias laut perlu ditingkatkan.

UKM Bahari Timur adalah salah satu UKM yang bergerak pada usaha perdagangan produk ikan hias untuk akuarium sejak tahun 2012. UKM Bahari Timur sampai saat ini merupakan salah satu yang memiliki ijin peredaran ikan hias laut untuk dalam negeri. Semenjak berdirinya UKM Bahari Timur samapai sekarang masih belum melakukan ekspor,

UKM Bahari Timur sebenarnya sudah mulai merintis sendiri untuk melakukan pengiriman secara domestik (Jakarta, Jawa, dan Bali) produk ikan hias namum terkendala dengan beberapa permasalahan yaitu (1) Produk ikan hias hasil tangkapan yang dipasarkan belum memenuhi kualitas pasar ekspor, (2) Belum bisa memilih jenis ikan yang berkualitas dari hasil tangkapan 30\%-50\% yang diterima dipasar (3) Cara menangkap ikan hias yang tidak ramah lingkungan. (4). Banyaknya kematian pada saat pemeliharaan di akuarium sebelum dipasarkan.

Teknik penangkapan ikan hias laut ini telah dilakukan dengan berbagai tingkat teknologi yang berbeda dalam hal masukan serta hasil yang diperoleh. Meningkatnya permintaan terhadap ikan hias air laut untuk beberapa daerah dan Negara tujuan ekspor dapat meningkatkan permintaan produksi ikan hias air laut itu sendiri (Perikanan et al., 2015). Faktor ketersediaan stock masih merupakan kendala dalam usaha penangkapan yang selalu tergantung pada alam untuk tujuan ekspor ikan hias laut. Untuk pemenuhan kebutuhan permintaan terhadap ikan hias laut pada daerah lain dan negara-negara tujuan ekspor, produksi masih tergantung dari hasil tangkapan dari alam, namun hanya mampu memasok kurang lebih $30 \%$ dari total kebutuhan akan hias air laut (Yoesdiarti, Masithoh, \& Lesmana, 2017). Disamping itu dari tahun ke tahun jumlah stock akan ketersediaan ikan hias air laut di alam cenderung menurun, sehingga muncul kesenjangan antara permintaan ekspor yang semakin meningkat dan ketersediaan stock yang belum terjaga secara berkelanjutan. Dengan adanya kesenjangan antara ketersediaan ikan hias air laut ini untuk tujuan ekspor yang semakin meningkat, maka diperlukan adanya penanganan dan pemeliharaan secara terkontrol dan berkelanjutan.

Dengan adanya kesenjangan antara ketersediaan ikan hias air laut ini untuk tujuan ekspor yang semakin meningkat, maka diperlukan adanya penanganan dan pemeliharaan secara terkontrol. Perairan Pulau Barrang lompo merupakan daerah yang mayoritas penduduknya nelayan, dalam mengelola suatu usaha perikanan khususnya ikan hias laut masyarakat Pulau Barrang Lompo masih sangat jauh tertinggal dan belum mengetahui cara mengelola perikanan (ikan hias) laut secara ramah lingkungan (Kasmi \& Karma, 2016).

(Abdullah, 2017) Inovasi terbukti memliki pengaruh signifikan dan positif terhadap keunggulan bersaing Indikator Inovasi produk, proses dan manajerial telah diterapkan sesuai 
dengan kondisi UMKM pengolahan rumput laut untuk meningkatkan keunggulan bersaing. Semakin tinggi inovasi yang dilakukan maka keunggulan bersaing semakin meningkat pula.

Oleh karena itu dalam inovasi Teknik Penanganan Produksi Ikan Hias Laut Berkelanjutan maka ikan hias laut merupakan potensi produk unggulan daerah yang menjadi primadona khususnya untuk pangsa pasar ekspor yang dapat mendatangkan pendapatan nelayan dan sumber devisa daerah. Tujuan Program Pengembangan Produk Unggulan Daerah (PPPUD) ini adalah mengembangkan kegiatan usaha sekelompok masayarakat nelayan yang lebih mandiri secara ekonomi yang profitable dan sosial, menciptakan ketentraman, kenyamanan dalam kehidupan bermasyarakat dan meningkatkan keterampilan secara softskill dan hardskill, memiliki pengelolaan organisasi dan keuangan yang benar, serta menjadi perusahaan yang sustainable hingga akhirnya memiliki dampak positif bagi nilai aset dan omset UKM, jumlah dan mutu produk meningkat untuk di pasarkan, pasar produk dapat terbuka luas sampai pada produk ekspor, perbaikan kesehatan lingkungan, dan peningkatan jumlah tenaga kerja UKM (Abdullah, 2017). Kemitraan yang dibangun dalam program ini adalah kemitraan antara perguruan tinggi dalam hal ini Politeknik Pertanian Negeri Pangkep dan UKM Bahari Timur.

\section{METODE}

Kegiatan pengabdian Program Pengembangan Produk Unggulan Daerah (PPPUD) ikan hias laut ini dilakukan pada Mei sampai dengan Oktober 2019 pada UKM Bahari Timur yang berada di Pulau Barrang Lompo, Kecamatan Sangkarrang, Kota Makassar.

Berdasarkan beberapa permasalahan dari mitra, maka dalam pelaksanaan program ini akan memprioritaskan permasalahan perbaikan kualitas produk dalam hal ini pengenalan alat tangkap yang ramah lingkungan yaitu jaring kleopatra dan penanganan hasil tangkapan ikan hias yang efektif.

Lebih jelasnya, langkah-langkah yang dilakukan dalam pelaksanaan PPPUD ini adalah sebagai berikut:

1. Sosialisasi program PPPUD untuk menyatukan persepsi tim pengabdi dan mitra dalam pelaksanaan program.

2. Peningkatan pengetahuan dan keterampilan mitra melalui pelatihan antara lain :

a. Pelatihan pembuatan jaring kleopatra

b. Pelatihan cara penangkapan dan penanganan ikan hias menggunakan jaring kleopatra dan minyak cengkeh

3. Operasionalisasi yang merupakan tahap penentu keberhasilan dari program PPUD ini.

4. Monitoring dan evaluasi program untuk menjamin keberlajutan dan pengembangan dari PPPUD ini.

\section{HASIL DAN PEMBAHASAN}

Perkembangan ikan hias bukan merupakan ikan konsumsi manusia tetapi merupakan ikan untuk pajangan, untuk dilihat karena keindahannya. Rasa suka manusia memajang ikan berwarna-warni beragam rupa dalarn wadah tembus pandang atau akuarium. Jenis atau metode penangkapan ikan yang kini dilarang hampir di seluruh dunia adalah dengan penggunaan racun kimiawi maupun racun (Anggoro, Suryanti, \& Marwadi, 2013).

Keragaman hayati yang besar dal;am bentuk ekosistem beragam dan wilayah yang demikian luas dengan jumlah pulau-pulau yang banyak menimbulkan kesulitan dalam pengelolaannya yang optimal, termasuk dalam pemanfaatan biota laut hias. Hal ini dapat ditunjukkan oleh sedikitnya minat pengusaha biota laut hias (Nailufar, Basito, \& Anam, 2012). Sebagian besar cenderung memiliki usaha aquarium hias air tawar yang memiliki resiko 
usaha rendah dibanding usaha aquarium hias laut dengan resiko tinggi. Minat masyarakat dunia dalam aquarium hias laut semakin meningkat sementara minat pengusaha dibidang yang sama masih kurang dan pangsa pasar semakin terbuka, maka pengembangan usaha biota aquarium hias laut perlu ditingkatkan (Kasmi et al., 2016).

Secara keseluruhan pelaksanaan kegiatan PPPUD Ikan Hias di Pulau Barrang Lompo telah terealisasi. Sebelum melakukan pelatihan, tim lebih dahulu mengadakan sosialisasi pengabdian PPPUD kepada mitra dalam hal ini kelompok nelayan yang tergabung dalam UKM Bahari Timur. Di mana, pengabdian kepada masyarakat merupakan salah satu wujud dari Tri Darma Perguruan Tinggi. Kegiatan tersebut diharapkan menjadi penghubung antara perguruan tinggi dengan masyarakat sehingga terjalin keharmonisan dalam aplikasi keilmuan.

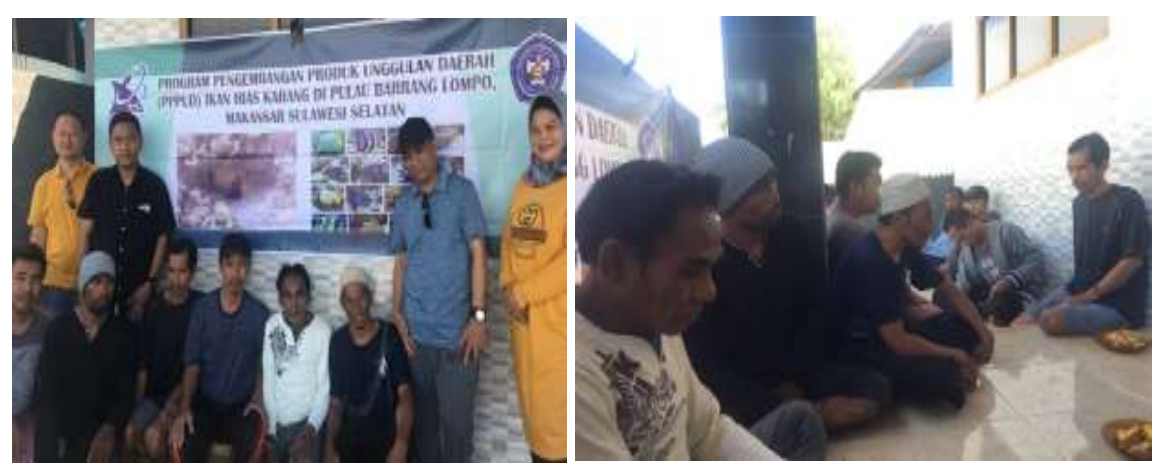

Gambar 1. Sosialisasi Program PPPUD

Kami juga memberikan pelatihan penggunaan alat tangkap ramah lingkungan yang menggunakan jaring kleopatra dimana manfaat penggunaan jaring kleopatra ini dapat menghalau ikan hias bukan untuk meningkatkan kualitas hasil tangkapan ikan yang pada akhirnya dapat menambah nilai jual ikan tersebut. Mitra pengabdian sangat antusias mengikuti kegiatan ini karena mereka mendapatkan alih teknologi pelatihan ini.

Pelatihan teknik cara penangkapan ikan hias yang ramah lingkungan dengan menggunakan jaring kleopatra yang diikuti oleh kelompok nelayan. Penangkapan dengan cara yang merusak lingkungan seperti penggunaan bahan-bahan kimia berupa sianida dilarang. Diharapkan nelayan penangkap ikan hias melakukan penangkapan yang diajurkan dalam kaitannya dengan alat tangkap ramah lingkungan.

Teknik penangkapan ikan hias laut ini telah dilakukan dengan berbagai tingkat teknologi yang berbeda dalam hal masukan serta hasil yang diperoleh. Meningkatnya permintaan terhadap ikan hias air laut untuk beberapa Negara tujuan ekspor pada gilirannya akan meningkatkan permintaan terhadap ikan hias air laut itu sendiri. Fakor ketersediaan stock masih merupakan kendala dalam usaha penangkaran untuk tujuan ekspor ikan hias laut ini. Pemenuhan kebutuhan permintaan terhadap ikan hias pada negara-negara tujuan ekspor, masih mengandalkan hasil tangkapan dari alam, namun hanya mampu memasok kurang lebih $50 \%$ dari total kebutuhan akan hias air laut. Disamping itu dari tahun ke tahun jumlah stock akan ketersediaan ikan hias air laut di alam cenderung menurun, sehingga muncul kesenjangan antara permintaan ekspor yang semakin meningkat dan ketersediaan stock yang belum terjaga secara berkelanjutan. 


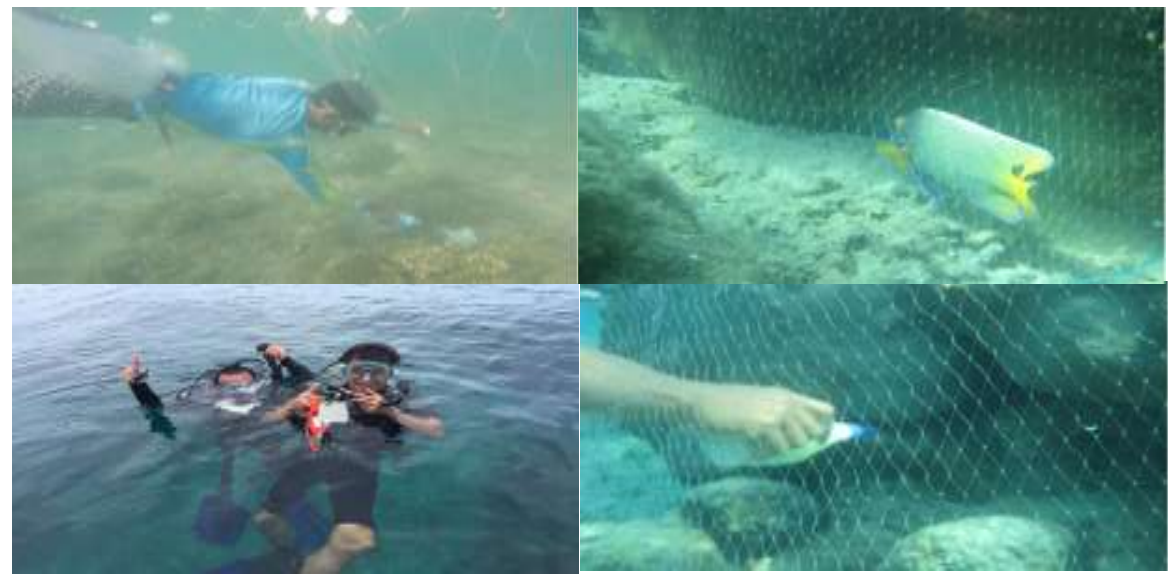

Gambar 2. Teknik Cara Penangkapan Ikan Hias

Kegiatan lain yang dilakukan adalah pelatihan atau penyuluhan penanganan hasil tangkapan ikan hias. Perawatan ikan yang meliputi pemeliharaan dengan pengelolaan lingkungan atau kualitas air, penanganan atau handling, serta penggunaan alat-alat harus dikerjakan dengan baik dan higiens. Pemeliharaan yang baik akan membuat ikan nyaman hidup di tempat itu. Wadah atau tempat pemeliharaan, seperti akuarium atau bak, sebaiknya disesuaikan dengan jenis atau ukuran ikannya,
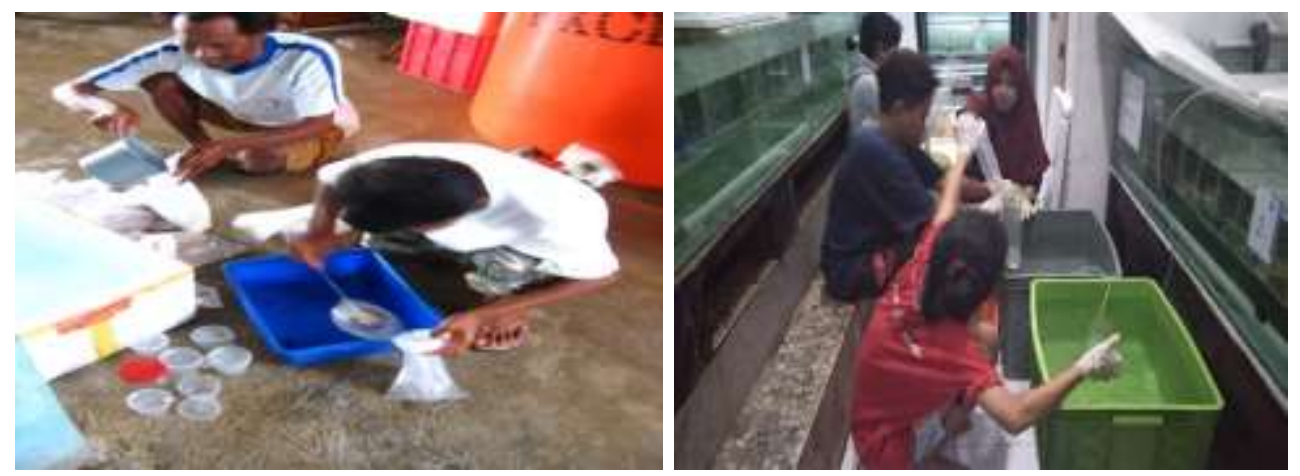

Gambar 3. Penanganan Ikan Hias Pasca Penangkapan.

Kelompok Nelayan dan penangkap ikan hias juga diberi penyuluhan tentang bagaimana mereka merawat kualitas dan suhu air dalam wadah untuk memastikan kesehatan optimal bagi ikan hias untuk akuarium. Hal ini dapat dicapai melalui beberapa cara, misalnya meliputi hal-hal berikut:

1) Tempat penyimpanan harus terhindar dari terik matahari / teduh

2) Sering mengganti air dengan air yang bersih

3) Mengurangi stres akibat tindakan-tindakan seperti pergantian air yang terlalu sering atau tidak tepat dan keteduhan yang berubah-ubah

4) Memastikan periode penyimpanan yang pendek antara penangkapan dan pengiriman kepada pembeli yang mampu melakukan aklimatisasi dengan tepat.

Kegiatan pengabdian juga dipublikasikan media online dengan tujuan mensosialisasikan kegiatan pengabdian sekaligus mempromosikan produk luaran dari kegiatan pengabdian PPUD Ikan laut hias. 


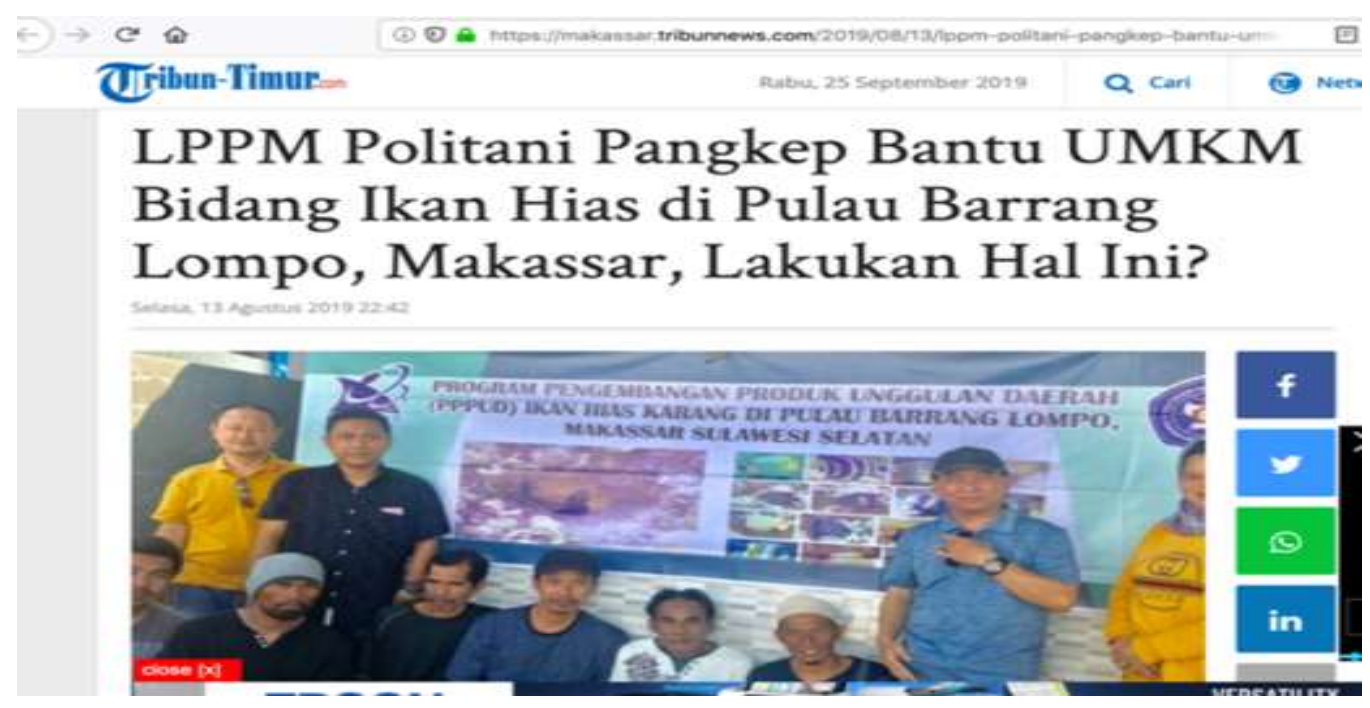

Gambar 4. Publikasi Media Online

\section{KESIMPULAN}

Berdasarkan hasil pelaksanaan kegiatan yang telah dilakukan pada Program PPPUD ikan Hias Air laut di Pulau Barrang Lompo Kota Makassa, dapat disimpulkan sebagai berikut

- Kegiatan yang dilaksanakan sangat direspon oleh mitra UKM . Hal ini dibuktikan dengan partisipasi dan kerjasama semua pihak hingga kegiatan berjalan baik dan lancar.

- Kehadiran program ini dapat memberikan solusi atas masalah yang dihadapi mitra ini yaitu pemberian teknologi tepat guna alat tangkap ikan hias ramah lingkungan

- Kegiatan yang dilaksanakan sesuai dengan kebutuhan mitra dan kebutuhan masyarakat untuk mencapai kehidupan mandiri dan sejahtera.

- Produksi ikan hias meningkat untuk mitra dari 30-50\% menjadi 70-80\% yang dapat diterima pasar

- Ikan hias laut sebagai primadona produk unggulan daerah karena manfaat ekonomi dari usaha ikan hias laut yang melibatkan kelompok nelayan secara keseluruhan terbukti mampu meningkatkan taraf hidup masyarakat nelayan.

\section{UCAPAN TERIMA KASIH}

Penulis berterima kasih kepada Direktorat Riset dan Pengabdian Kepada Masyarakat, Direktorat Jenderal Penguatan Riset dan Pengembangan, Kementerian Riset, Teknologi, dan Pendidikan Tinggi yang telah membiayai pelaksanaan program PPPUD ini. Tak lupa pula kami ucapkan banyak terima kasih kepada bapak Direktur Politeknik Pertanian Negeri Pangkep, pengelola Pusat Penelitian dan Pengabdian Masyarakat Politeknik Pertanian Negeri Pangkep, Mitra UKM Bahari Timur, serta Pemerintah Kota Makassar yang telah bekerjasama dalam pelaksanaan kegiatan ini.

\section{DAFTAR PUSTAKA}

Abdullah, A. (2017). Inovasi, Orientasi Pasar, Kompetensi dan Orientasi Kewirausahaan Pengaruhnya Terhadap Keunggulan Bersaing dan Kinerja Pemasaran Pada UMKM Pengolahan Rumput Laut di Sulawesi Selatan. Universitas Muslim Indonesia. 
Agribisnis Perikanan, J., Pertanian Negeri Pangkep Mauli Kasmi, P., \& Pertanian Negeri Pangkep, P. (2015). The Habitat Characteristics Relation With Ornamental Fish Abundance Angel Fish (Pomacanthus imperior) Pangkep Waters, South Sulawesi. Jurnal Galung Tropika, 4(3).

Anggoro, S., Suryanti, S., \& Marwadi, A. (2013). Pengaruh Penggunaan Alat Tangkap Ikan Hias Ramah Lingkungan Terhadap Tingkat Kerusakan Terumbu Karang Di Gosong Karang Lebar Kepulauan Seribu. Diponegoro Journal of Maquares (Management of Aquatic Resources).

Kasmi, M., \& Karma, A. (2016). The Relationship between Blue-Girdled Angelfish (Pomacanthus Navarchus) Exploitation and Availability for a Sustainable Fishery in South Sulawesi. Journal of Agricultural Studies. https://doi.org/10.5296/jas.v5i1.10511

Kasmi, M., Nessa, M. N., Jompa, J., Perikanan, J. A., Pertanian, P., \& Pangkep, N. (2014). Struktur Ukuran, Pertumbuhan Dan Rasio Seksual Ikan Hias Napoleon (Pomacanthus xanthometopon ) Di Perairan Sulawesi Selatan Size Sructure, Growth And Sex Ratio Of Ornamental Angelfish ( Pomacanthus xanthometopon) in The Waters of South Sulawesi. 283-294.

Nailufar, A. A., Basito, \& Anam, C. (2012). Kajian Karakteristik Ketan Hitam (Oryza sativa glutinosa) pada Beberapa Jenis Pengemas Selama Penyimpanan. Jurnal Teknosains Pangan.

Perikanan, J. A., Pertanian, P., Pangkep, N., Kasmi, M., Perikanan, J. A., Pertanian, P., \& Pangkep, N. (2015). Karakteristik Habitat dan Kelimpahan Ikan Hias Injel Batman (Pomacanthus Imperior) di Perairan Kabupaten Pangkep, Sulawesi Selatan The Habitat Characteristics Relation With Ornamental Fish Abundance Angel Fish ( Pomacanthus imperior ) Pangkep Waters ,. 4(3), 164-172.

Yoesdiarti, A., Masithoh, S., \& Lesmana, D. (2017). Strategi Pengembangan Agribisnis Ikan Hias Di Kecamatan Ciomas Kabupaten Bogor. Jurnal Mina Sains. https://doi.org/10.30997/jms.v3i2.892 